\title{
Ethical Functions of Newspaper Editorials in Nigeria's Anticorruption Campaign
}

\author{
Omozuwa, Osamwonyi Gabriel \\ School of Media and Communication, Pan Atlantic University, KM 52 Lekki-Epe Expressway, Ibeju-Lekki, \\ Lagos \\ Email of corresponding author: osamwonyi.omozuwa@pau.edu.ng
}

\begin{abstract}
Using the three dominant frameworks of normative ethics, namely; deontology, utilitarianism, and situational ethics, this paper explores the functions of newspaper editorials in Nigeria's anticorruption crusade. It is premised on the notion that endemic corruption is a manifestation of ingrained unethical principles that subordinate public good to private enrichment. Newspaper editorials being hallmark of ethical communication, and epitome of the moral messages of media, contribute to attenuating corrupt practices by scrutinising power and espousing norms of accountability, probity, and transparency. The paper highlights the links between ethics and rhetoric. It explores how deontology, utilitarianism, and situational ethics converge with forensic rhetoric, epideictic rhetoric, and deliberative rhetoric in editorial. It also considers the challenges militating against editorials as stimulus of ethical renewal. It ends with conclusion, and recommendations.
\end{abstract}

Keywords: Editorial, Ethics, Anticorruption, Transparency, Editorial Independence, Rhetoric, Public Discourse.

DOI: $10.7176 / \mathrm{NMMC} / 100-05$

Publication date: February $28^{\text {th }} 2022$

\section{Introduction}

Newspaper editorials play seminal roles in strengthening the ethical foundation of democratic societies. Editorialists recognize the fact that good governance and sustainable development do not happen in ethical vacuums. Their polemical discourse helps to advance the anticorruption war as they espouse ethical concepts of accountability, probity, and transparency, which are cornerstones of effective public resources management and sustainable development. Editorialists expose conducts that do not protect public interests, deviate from national aspirations or conflict with ethical norms. In fact, the stigmatization of acts that violate the law is their second nature. This has fostered a public consciousness that perpetrators of corrupt acts are liable to become objects of vituperative contempt.

Ethics is closely related to moral philosophy (Stokhof, 2018). It is commonly seen as learned habits of the mind that enable moral reasoning about the appropriateness or inappropriateness of any human conduct, particularly, in relation to the pursuit of happiness. Therefore, ethics is central to the flourishing life, and its indispensability in a nation's quest for inclusive development (Adegbami \& Adepoju, 2017), in part, explains why it is a key motif of newspaper editorials in Nigeria.

Newspaper editorials encapsulate the essence of free purveyance of ideas in any liberal-pluralistic democracies. They contribute to the consolidation of democratic ethos by educating, informing, entertaining, correlating the environment, transmitting cultural values, and influencing social norms. Editorial contents promote transparent government operations, adherence to standard operating procedure; and reification of anti-corruption strategies. Hence, they are seen as the "heart and soul, the one area where the personality and, more important, the philosophy of the newspaper can most properly be expressed" (Pratt, 1990).

Editorials serve as good examples of rational moral tutors. They are upholders of ethos of responsibility and accountability, sentinel of citizens' right, defenders of equity. In fact, editorials by reflecting the conscience of society function as moral compass, and ethical guideposts. They urge and nudge trustees of peoples' power to discharge their responsibilities while adhering to norms of accountability.

These socio-ethical functions are germane in view of the fact that corruption is endemic in Nigeria. The 2020 corruption perception index (CPI) report, which was published by Transparency International (TI), shows that Nigeria ranks 149 out of the 180 countries surveyed. The report indicates, Nigeria scored 25 out of 100 points. It also reveals that Nigeria is the second most corrupt nation in West Africa, while Guinea-Bissau is the most corrupt, ranking $165^{\text {th }}$ out of 180 . The ubiquity of corruption in Nigeria vitiates democracy. It subverts 
development, reduces direct foreign investment, makes fair business competition problematic, and makes dividends of democracy elusive. Also, corruption compromises Nigeria's territorial sovereignty, and the legitimacy of state institutions.

In view of the multidimensional effects of corruption, the 1999 Constitution as amended notes that, it is a deontic duty of the state to "abolish all corrupt practices and abuse of power." In line with this constitutional provision, at the incipience of the Fourth Republic, the federal government established two anticorruption agencies, namely; the Economic and Financial Crimes Commission (EFCC), and the Independent Corrupt Practices Commission (ICPC), (Yusha'u, 2018).

Similarly, the constitution made provision for the press to be a veritable promoter of accountability. In section 22, it states: "The press, radio, television and other agencies of the mass media shall at all times be free to uphold the fundamental objectives contained in this chapter and uphold the responsibility and accountability of the government to the people". In discharging its explicit constitutional mandate, the press functions as a watchdog, and a rational ethical educator. It canvasses principles that could reduce the prevalence of corruption.

Newspaper editorial like many baggy terms is multivocal. Its plethora of definitions reflect different elements of the editorial, not necessarily definitional dissonance. Therefore, it is apposite to consider a few. According to Sinclair (1995) an editorial is; "an article in a newspaper that gives the opinion of the editor or publisher on a topic or item of news." Tobechukwu and Olaitan (2009) opine that, editorial is an "article in a newspaper or magazine written by the editor or under his direction, giving the opinion or attitude of the paper upon some subject." Editorials are a specific form of opinion texts in newspaper. They seek to persuade readers. Belmonte (2008) notes that editorials are "mass communicated types of opinion discourse" that influence "the formation and altering of public opinion." Editorial expresses well-considered opinions of a newspaper on specific subject matters (Bhatia,1993). They represent institutional viewpoints, ethical leanings, and are epitome of persuasive writing. Furthermore, newspapers editorials are typically unsigned, and they regularly appear in a particular place. However, in a broader sense, newspaper editorials include letters to the editors, and signed opinion articles written by members of the public (Bhatia,1993).

Newspaper editorials are dynamic. A diachronic study of variation in British newspaper editorials by Westin (2001) shows that they "became more argumentative but less narrative." Its dynamic evolution enables it to keep meeting the changing needs of the reading public, and maintain its primacy in its sub-genre of opinion discourse. Also, it helps editorials to remain relevant in the present media ecology, which is characterized by multiplicity of voices and dissonant ideologies. Some of these changes have made the newspaper editorials more explanatory, analytical, punchy, concise, and well oriented towards serving the interests of divergent readers (Hynds and Martin, 1979).

\section{Functions of Newspaper Editorials}

Editorials offer opportunities to understand how newspapers perceive and respond to the existential and ethical challenges in their socio-moral milieu, and polity. They are not merely sites of constructive criticisms where upholders of accountability anatomize public policies, projects, and programs, they are also didactic hub of value reorientation for civic propriety and good governance. Le (2008) opines editorials "tell us what media 'do' in the public sphere". Against the backdrop that, Nigeria is battling with the multidimensional challenges of corruptions, the role of the press as a moral educator is assuming increasing significance. In Nigeria's public sphere as in most places with vibrant and free press, editorials serve as instrument of issues identification, ethical advocacy, setting agenda for public deliberations, analysis of facts and figures, contestation of ideas, and interpretation of social phenomena (Mott,1940). Greenberg (2000) notes that, newspaper editorial "assumes an important communicative function by offering newsreaders a distinctive and authoritative voice that will speak to them directly, in the face of troubling or problematic circumstances." This means that typically equivocation and turbidity are not qualities of editorials. Their usefulness to a great extent is a function of their clarity, conciseness, pointedness, and topicality. 
Editorials are instrumental to setting agenda for public discourse. Editorial contents often become staple of public contemplations, deliberations, and debates. They often sway and guide public opinion; because, they are typically rational, in-depth analysis of issues of public salience. Their eschewal of jingoistic slogan stimulates collective contemplations and deliberations. In fact, their mode of argument incites rather than smother thought. Furthermore, Greenberg (2000) notes that they play notable "communicative function by contributing to the media's role of formulating certain, "preferred' viewpoints about the world." This process of influencing social cognition equates to "constructing an ideology of consensus." (Greenberg, 2000). The influence of editorial on formation of opinion is powerful and extends beyond the sphere of "everyday reader" to vital institutions (Greenberg, 2000).

Editorials also contribute to the processes of policymaking and analysis. Being authoritative voices of newspapers, their canvassed ideas and opinions contribute to policy debates. This is largely due to the fact that, generally, editorials speak without equivocating, particularly, "in the face of troubling or problematic circumstances" (Greenberg, 2000). Furthermore, editorial writers contribute meaningfully to public debates, because of their vantage position, which enables them to have panoptic views of society, and feel public impulses.

Editorials enable newspapers to speak with their own voices, not to merely echo the voice of power. In Nigeria, right from colonial era through to military rule and the return to democratic governance in 1999, newspapers use their voice to curb rising socioeconomic maladies. Their fact and evidence-based anatomizations of social phenomena promote widespread public understanding. This is important since public knowledge is a prerequisite for collective action and social change. To a great extent, the power of editorials as agents of social transformation derives from their fidelity to objective facts, and lucid portrayal of ontic realities. They are mostly a composite of what van Dijk (1998) classifies as "evaluative propositions" (normative prescriptions) and "factual beliefs" (social facts).

Editorials provide thought leadership in Nigeria's anticorruption war. They are generally recognized by influencers, opinion leaders, academia, social reformers, policymakers, anticorruption crusaders, et cetera as credible sources of evidence-based knowledge, objective information, distinctive seminal ideas, uncommon and valuable perceptive. Also, editorials are often a clarion call to collective action. According to Omojola (2005) due to the persuasive nature of editorials, they serve as instrument of mass mobilization for social change. It is one of the ways newspapers help to orient the public, entrench civic ideals, and achieve institutional reforms.

Furthermore, editorials put the actions and inactions of men and women of power under public scrutiny. As a result, public officeholders are aware that their reputation is vulnerable to damage, if they perpetrate corrupt acts. Most often, public awareness of acts of corruption instigates name-and-shame game, which disincentivizes corruption.

Ernest C. Hynds (1984) sought to know the general functions of editorials from the perspective of editors in the United States. Therefore, he conducted a survey. The following are the answers that emanated: "attract readers to the papers," "educate readers on issues," "sort out important issues and stimulate readers' thought on them," "help readers understand trends and developments," "stir the community in hopes of gaining public opinion response," "reflect the wants and needs of the community," "permit public access to the medium," "encourage a local exchange of ideas," "make people think," "entertain and challenge readers," "criticize official malfeasance," "evaluate candidates for public office," "be a kind of public conscience in the community," and "establish the character of the newspaper."

Following the above, Hynds (1984) notes that the significance of editorials to sustainable human and national development is accentuated by the fact that they influence readers' perceptive about issues in their immediate environment and help them make sound judgements (Pratt, 1990). Hynds (1984) further notes that editorial "provide community leadership through stands on issues." This points to the hierophantic element of editorials. They explain the back story. Hence, they help readers to have comprehensive understanding of trending issues, while eliciting the pleasure of educative and informative experiences. 


\section{Common Types of Newspaper Editorials}

There are different types of editorials. Tobechukwu and Olaitan (2009) identified six types that are prevalent in Nigerian newspapers. They include news editorial, social editorial, special editorial, tribute editorial, policy editorial, and speculative editorial. Furthermore, Tobechukwu and Olaitan (2009) noted that there are also critical, condemnatory, expository or persuasive editorials, noting that, the critical editorial is common in Nigeria newspapers, because of the many socio-political issues bedevilling the nation. Here the goal is not to elaborate on the different types of editorials, but to highlight their link with rhetorical conventions in subsequent section. Nonetheless, it is important to briefly examine few.

The editorial of information also known as news editorial focuses on issues in the news. They have newsworthy elements and are explanatory. Largely, they are informed by news peg, and often provide extensive factual details of news stories. On the other hand, the editorial of interpretation seeks to clarify complex issues, explain the significance of a news event or social phenomenon in ways that are void of value judgments. It presents the various sides of an issue, in an explanatory manner. For example, an editorial that focuses on annual budget or policy documents.

There is also the editorial of criticisms. Its overriding objective is to influence readers by accentuating the good and the bad elements of an issue of public concern. It is somewhat related to the editorial of argumentation or persuasion. The editorial of argumentation inheres the principles of logical persuasion. Its core objective is to change readers' viewpoints on burning national or global issues. It marshals facts, figures, and relevant data to make a case.

\section{Corruption in Nigeria}

The genesis of corruption in Nigeria is slightly aporetic. However, it is commonly traced to colonial era. According to Okolo and Raymond (2014) "Colonialism introduced systemic corruption on a grand scale across much of sub-Saharan Africa." Colonial rule started with the cession of Lagos Island and her surroundings by Oba Docemo to the British Crown in 1861. Okolo and Raymond (2014) note that in pre-colonial eon, corruption was alien. Colonialism eroded the ethos of Afro-spirituality. The foundations of traditional African societies were built on strong moral, ethical, and spiritual values that promoted social justice, equity, and fairness. But colonial rule perverted the nature of leadership in Nigeria, making corruption its soul (Okolo and Raymond, 2014). For example, the indirect rule made leaders to hold power not in trust for the people, but in trust for the colonial overlords.

During colonial rule, some high-profile corruption scandals were recorded. One of such scandals eventuated the first Commission of Inquiry on July 24, 1956. The Commission, headed by Justice Strafford Forster, investigated the African Continental Bank (ACB). For, a highly placed politician with significant business interest in the bank allowed public funds to be invested in it. In 1962, the relationship of the premier of Western Region with National Investment and Property Company, which owed the regional government the sum of $£ 7,200.00$, aroused political tension. As a result, the Federal Government instituted a panel of inquiry to investigate the allegation. Eventually, the then premier was indicted. Also, the properties of the company were forfeited to the government of Western Region (Sowunmi, 2010). However, corruption became pervasive and consolidated in the loci of power during the 29 years of military rule in Nigeria (Sowunmi, 2010).

In Nigeria, corruption survives due to weak governance. Weak institutions enable powerful public officeholders to enjoy some sorts of monopolistic, discretionary, and unaccountable power. Corruption has different forms of manifestations and occurs across different strata of society. "It takes place at the grassroots level and affects people's daily lives, for example through bribes paid to bureaucrats, or non-delivery of services to poor people. The corrosive effect of corruption undermines all effort to improve governance and foster development." (Yusha'u, 2018). Apart from accepting bribes, corruption entails violation of standard procedure for contract award, opacity of government business, political interferences in judicial processes, budget padding, falsified public records for private gains, et cetera. 
Corruption is a key retardant of sustainable and inclusive development in Nigeria. It undermines territorial and state legitimacy. Ubiquitous abuse of public power for private enrichment disincentivizes investment, increases cost of transactions, and makes the business climate hostile, thereby, reducing the pace of economic development, and increasing the rate of unemployment. The endemic nature of corruption has compelled some multinationals to relocate their businesses from Nigeria to neighbouring nations. The effects of corruption could also be seen in the prevailing infrastructural deficit, and the readiness of some citizens to sabotage state enterprises: For example, Nigerian Telecommunication Limited; Nigerian Airways; Steel Rolling Mills; National Shipping Lines; and so on (Stople,2008).

The inordinate wealth-hunting, power-grabbing conduct, and venality of many public officeholders have deeply entrenched corruption. Public resources are not used prudently and ethically to secure the greatest good for the highest number of people. It is estimated that "Between 1960 and 1999, Nigerian officials had stolen or wasted more than $\$ 440$ billion. That is six times the Marshall Plan, the total sum needed to rebuild a devastated Europe in the aftermath of the Second World War" (Yusha'u, 2018).

Miftahu Idris (2020) shows that the huge scale of Illicit capital flight from Nigeria is a contributary factor to economic retardation, and high unemployment rate. According to United Nations (UNCTAD, 2020), "Nigeria accounts for an estimated 46 per cent of the capital flight on the continent, based on average estimates for 2013 and 2015, and 80 per cent of the capital flight in Western Africa." A diachronic examination of illicit transfers indicates that in about two decades, about $\$ 89$ billion, which is equivalent to 18.69 per cent of Nigeria's Gross Domestic Product (GDP) was illegally transferred out of the nation. The UN notes that there is empirical "evidence of the two-way relationship between corruption proceeds and origins of illicit financial flows. On one hand, corruption facilitates money-laundering and on the other hand, money-laundering makes grand corruption possible and profitable" (UNCTAD, 2020),

\section{Ethics in Editorials}

It is important to state that editorialists are not essentially ethicists. This implies, they do not intentionally set out to apply normative theory of ethics to remedy Nigeria's flawed moral system. However, as canvassers of norms of good governance, they knowingly or unknowingly put forward for public contemplation ethical values. The ethical values inherent in editorials, which focus on anticorruption could be classified into three dominant subsets, which are; deontological; situational ethics, and teleological.

Deontology focuses on "what ought to be done." It foregrounds moral obligation, nobility of intention, and deemphasises consequence of action. It does not see consequences as a pivotal evaluative criterion of moral goodness or wrongness. Deontologists examine the moral merit of an action in relation to duty. They consider certain actions as inherently good, for example; virtue, knowledge, pleasure, and so forth. Similarly, the relational implication of an action determines its moral rightness. A demonologist inclination to objective values enables him or her to subordinate personal happiness and consequence to "categorical imperative". Immanuel Kant posits that "categorical imperative" is the grand rule, or the super-principle that govern the rule of conduct.

In Nigeria, the critical editorial often exudes elements of deontology. They present duty as evaluative standard for action and thought. Doing the needful equates to ethical prudence. Therefore, when public officers fail to do what ought to be done, or deviate from the stipulated principles of action, they are subjected to public scrutiny and criticisms.

The second approach is situational ethics. A situational ethicist has conditional affinity to definite ethical principles. Circumstantial exigencies regulate the conducts of situationists. This is, because, they do not have fixed concept of moral rightness or wrongness. They esteem outcomes above principles, and approach ethical issues from the path of relativism. Outcomes are their true standard for action and thought. Their prime rationale for applying a moral principle is its circumstantial appropriateness, contextual relevance, and possible results, not objective value. 
Although many editorialists in Nigeria are not avowed adherents of situational ethics, yet, their inclination to see certain social phenomena with ethnoreligious-tinted lenses, present many of them as situationists. Deeply ingrained ethnoreligious sentiments make them to espouse the fundamentals of ethical relativism. This is most evident when a member of their ethnoreligious clan allegedly violates ethical rules of governance. In Nigeria's politics and culture, ethnoreligious parochialism has been elevated above ethical principles. This unreasonable elevation exerts insidious influences on editorial content.

The tribute editorial and social editorial often exude norms of situational ethics. In them, affluent socialites without credible means of wealth are eulogized. Critical questions are not raised about their sources of wealth and obscene luxury. What they have, their power and glory are highlighted without examining who they are, and what they do or do not do to protect public interest.

The third dominant theoretical approach to ethics is teleology. Teleology is also referred to as utilitarianism or consequentialism, because, it examines an action in relation to its utility. This approach considers the moral goodness of an action based on its inherent benefits. In other words, an action is morally acceptable, if it promotes and optimizes the common good. Moral prudence or goodness is predicated on the beneficence of an action. Therefore, the moral rightness of an action is unquestionable, if it secures the "greatest happiness for the greatest number".

The editorial of information, which focuses on issues in the news with the aim of clarifying their complexities, are often premised on utilitarian logic. For example, a budget proposal based on its promise to provide the greatest benefits to most Nigerians will be deemed as good and ethically sound. Any item on the budget that might promote public good is subjected to criticism.

\section{Ethics and Rhetoric in Editorial}

Julien Dieudonné and Michael Syrotinski( 2004 ) note that rhetoric is referred to as "purposive communication", therefore, it is akin to editorial. Thomas Jesse Roach (2006) posits that; "Newspaper editorials and news stories are a hybrid of rhetorical conventions that serve the unique demands of public discourse in a mass democracy." There are three basic rhetorical conventions, namely; "forensic rhetoric", "epideictic rhetoric", and "deliberative rhetoric" (Richardson, 2007). Each of these rhetorical conventions could be differentiated based on where they are situated in the time continuum: then, now, later, or past, present, future. These rhetorical categories have a manifest governing virtue: expedience is the operating virtue for deliberative rhetoric, justice is the governing virtue for forensic rhetoric, while honor is the governing virtue for epideictic rhetoric.

Forensic rhetoric encompasses adjudicative, argumentative discourse of past action. It is concerned about wrongdoings, deliberate acts of inflicting harm, contraventions of ethical principles or the law. It condemns or defends past actions of a person or people. It is always about "then", what has happened.

Forensic rhetoric almost always imbues critical editorials. In relation to anticorruption, critical editorials that employ forensic rhetoric focuses on wrongdoers, the wronged, and the need for justice. Editorial anatomization of wrongdoings happens within ethical frameworks. Due to the merging of forensic rhetoric with ethics in critical editorials, the press has gained the reputation of court of public opinion. The court of public opinion attempts to exercise the right of the public to examine the judicial process as well as the right of the accuser and accused to fair legal proceedings. However, the drawback is that when the accused wins in a legal court, he often suffers reputational damage due to critical attacks and counterattacks in the court of public opinion.

Epideictic rhetoric deals with praise and blame. It denotes a form of discourse that provides examples worthy of admiration or disapproval. By so doing, it often blends moral claims, nonmoral claims, and factual claims to burnish the image of its subject. Its focal communication objective is to underscore the good qualities of people or phenomena, or the bad qualities as revealed by present circumstance. It is concerned about now, what is happening at the moment. 
Epideictic rhetoric invigorates tribute editorial. When aptly used, it inspires people to eschew the pedestrian, and embrace the noble. One of its functions in newspaper editorials in relation to Nigeria's anticorruption crusade is to stigmatize the antitypical, unethical public officeholders, and lionizes the ethical public officeholders. In a culture where praise singing is a norm, tribute editorials are prone to crossing the line between epideictic rhetoric and hagiographic writings.

It is important to state that epideictic rhetoric could be deployed in service of teleological, utilitarian or situational purposes. It could be argued that it is a deontic responsibility of editorialists to foreground how the moral prudence of accountable leaders is driving sustainable national development. The converse is also true. It is incumbent on editorialists to denounce unethical public servants, and show how they are retarding national development.

Deliberative rhetoric considers the desirability or loathsomeness of a decision that is to be made. It focuses on future outcomes. It critically examines what is to be done hereafter, and offer informed advices. This rhetorical convention is most manifest in editorial of information.

Deliberative rhetoric compares possible outcomes. This is done with the aim to elicit public support or opposition to a specific social action, policy initiative or bill. It uses past experiences to prognostic policy outcomes. It canvasses support for initiatives that have low risk and high benefits, and opposes those that have high risk and low benefit. By focusing on future harm or benefit of an action, deliberative rhetoric is more inclined to utilitarian ethics than others. Deliberative rhetoric is the lifeblood of editorial of information. For example, when looking at the annual budget of the federal government it highlights and explains its utilitarian quality to spur citizens' support.

\section{Challenges}

Many challenges have hindered the consistent editorialization of corruption-related issues from triggering widespread ethical renewal in Nigeria. One of such challenges is what Muhammad Jameel Yusha'u (2018) calls regional parallelism. Regional parallelism denotes the nefarious ethnoreligious divide between the north and the south of Nigeria. This divide tends to obscure the absolute difference between right and wrong. Regional parallelism also denotes the use of ethnoreligious sentiments to approbate unethical conducts of kinsfolks, or to reproach the ethical conducts of public officeholders from another region. This tendency relativizes ethical standards. It makes norms of proper public conduct fluid, situational and context determined.

Regional parallelism makes definite standards of evaluating right and wrong amenable to clannish sentiments. Kinsfolks of alleged lawbreakers irrationally attack fundamental ethical notions of duty, responsibility, probity, accountability, in order to subjectivize objective values, and vindicate violators of laws. The press is not immune from this tendency. It often takes sides. Sometimes, due to ethnoreligious affinity, editorialists distort or omit facts in order to construct a seeming halo of probity around alleged lawbreakers. This makes editorials prone to credibility deficit, and emasculation of their power as rational moral educators.

Another challenge that vitiates the power of the editorial to activate ethical transformation in Nigeria is the general malaise in the polity. Tony Momoh (2002), aptly underscores this challenge when he rhetorically asked: "How can we as media practitioners operate in a polity where everyone breaks the rule, where the journalists are poorly paid or not paid at all, where record keeping is so defective that people can pay their way out of crimes, where the officials who are supposed to give information hoard it; where there is total loyalty to the family and the ethnic group and ritual protection for their misdeeds; where those who should serve enslave the people through robbing the treasury?"

As Momoh (2002) notes, poor remuneration of journalists also constitutes a huge challenge. It makes journalists to render unethical services to "political contractors." Shuaibu Usman Leman (2014) aptly buttresses this by 
citing a former president of the Newspaper Proprietors Association of Nigeria, Late Chief M.K.O. Abiola; "If you do not pay your journalists well, someone else will pay them and they will work for him".

Most journalists are always under financial pressure, because of unpaid salaries. Muhammad Jameel Yusha'u (2018) notes that, "Many of the respondents cited an example with one of the leading newspapers in the country whose proprietor distributes identity cards to his staff and leave them to survive on the courtesy of their sources." Unpaid salaries and poor remuneration have contributed to the prevalence of nonadherence to journalistic code of ethics. It has institutionalized the brown envelope syndrome. Brown envelope syndrome weakens the culture of investigative journalism. It relegates objectivity, fairness, balance and accuracy to the background. It makes it morally burdensome for many journalists to canvass reforms aimed at making government operations more transparent and inclusive.

Another critical challenge that has eroded the credibility and transformative capacity of newspaper editorials in Nigeria is non-avoidance of partisan alignments. Ethically bankrupt publishers and editorial writers maintain opportunistic alliances, which encourage distortions of facts for monetary rewards. Opportunistic alliances are a cause of editorial interferences. Shuaibu Usman Leman (2014) identifies editorial interference as a key challenge undermining the ethical functionalities of the press in Nigeria. According to him, two newspapers based in a particular city published similar editorial within 24 hours. The focus of the editorials was on the disputed relevance of a government agency, and they had "the incredible coincidence of identity of opinion and in a few places phrasing and words" (Leman, 2014)

\section{Conclusion and Recommendations}

This paper highlights the fact that newspaper editorials in Nigeria perform various socio-ethical functions, and are veritable instruments of extirpating corruption from the national psyche. Editorials employ forensic rhetoric, epideictic rhetoric, and deliberative rhetoric to espouse deontological; situational, and teleological ethical ideals that could lead to the attenuation of corruption. Situational ethics cannot contribute significantly to the ablation of corrupt practice from the collective psyche of Nigeria; hence, it should not be a motif of editorials. A confluence of factors works in harmony to undermine the efficacy of editorials in Nigeria's anticorruption war. Some of these factors or challenges are; poor remuneration, regional parallelism, widespread malaises in the polity, editorial interferences, and opportunistic allegiances.

In view of the above, to enhance the effectiveness of newspaper editorials in the war against corruption, it is recommended that publishers and editors should eschew opportunistic allegiances that undermine the credibility index of editorials. This is imperative since demonstrating blind support for alleged perpetrators of corrupt acts would institute a culture of trifling with objectivity, facts, and verifiable evidence. Similarly, they should protect the sanctity of editorials by refraining from rehashing simplistic ethnoreligious sentiments that fan embers of divisiveness. The logic of region parallelism is inimical to the ethical foundation of a strong, united, and progressive nation. Also, to tame unprofessional tendencies of journalists, their remuneration should be commensurate with that of other professionals.

Furthermore, for editorials to contribute the utmost to the extant anticorruption crusade, it is imperative for editorialists to consistently familiarise themselves with various ethical traditions, this requires learning, unlearning, and relearning. Towards this end, Nigeria Guild of Editors should play strategic roles by organising seminars, conferences, and training programmes aimed at deepening ethical journalism, and making editorialists function effectively as public intellectuals, and guardians of public morality.

\section{References}

Abati, R. (1998). Press Freedom in Nigeria: 1859-1998, in Atere, A.A. and Olagbemi, A. eds., Communication, Language and Culture in Society, Lagos: Bolaji and Associates 
Adegbami, A. and Adepoju, B. M. (2017). “Good Governance in Nigeria: A Catalyst to National Peace, Stability and Development". African Research Review, Vol. 11 (4), No. 48, pp. 144 -155

Ahmadi, H., and Safaei Asl, E. (2013). Editorials and ideologies. International Journal

of Science Culture and Sport . 1(4), 11-21.

Ansary, H. and Babaii, E. 2009. A cross-cultural analysis of English Newspaper editorials: a systemic-functional view of text for contrastive rhetoric research. RELC Journal 40.2:211-248.

Bennett, W.L. (1996). News: The politics of illusion. 3rd ed. White Plains (NY): Longman.

Bhatia V.K. (1993). Analysing genre: Language use in professional settings. London: Longman.

Biber, D. (1988.) Variation across speech and writing. Cambridge: Cambridge University Press.

Bolivar, A. (1994). The structure of newspaper editorials. Advances in written text analysis. R. M. Coulthard. Ed. London: Routledge.

Belmonte, A, I. (2008), “Newspaper Editorials and Comment Articles: A Cinderella Genre?”, in A. I, Belmonte, (ed.), Different Approaches to Newspaper Opinion Discourse , http://dialnet.unirioja.es/servlet/articulo?codigo $=2546733$

Connor, U. (1996). Contrastive rhetoric: Cross-cultural aspects of second-language writing. New York: Cambridge University Press.

Dieudonné, J. \& Syrotinski, M (2004). The Power of Rhetoric, the Rhetoric of Power: Jean Paulhan's Fiction, Criticism, and Editorial Activity || The Power of Poetics, the Poetics of Power. Yale French Studies iss. 106

Ekeanyanwu, N.T. (2005). The Nigerian press and political conflict reporting: A case study of the Ngige-Ubah Political Conflict in Anambra State. In Yakubu, A.M. (ed.). Crisis and conflict management in Nigeria since 1980. Kaduna: Nigerian Defence Academy, pp. 221- 235

Ekeanyanwu, N.T. (2005). International communication: Issues, concepts and Researches in the $21^{\text {ST }}$ Century. Akure: Standard Mass Concept Company.

Hynds, E. C. (1984). Editorials, Opinion Pages Still Have Vital Roles at Most Newspapers. Journalism Quarterly 61.

Hynds, E.C., \& Martin, C. H. (1979). How Non-Daily Editors Describe Status and Function of Editorial Pages. Journalism Quarterly 56

Farrokhi, F. \& Nazemi, S. (2015). The Rhetoric of Newspaper Editorials. International Journal on Studies in English Language and Literature (IJSELL) Volume 3, Issue 2, PP 155-161

Greenberg, J. (2000), “Opinion Discourse and Canadian Newspapers: The case of the Chinese 'Boat People' “, Canadian Journal of Communication Corporation, Vol 25, No 4, PP. 517-537.

Hynds, E.C. (1976) 'Editorial Pages Are Taking Stands, Providing Forums," Journalism Quarterly. 53:532-5

Hynds, E. C. and Martin C.H. (1978). 'Editorial Writers Tell How They Go About Their Work." Journalism Quarterly. 54776-9

Hynds, E.C. and Martin C. H. (1979). How Non-Daily Editors Describe Status and Function of Editorial Pages. Journalism Quarterly/if. W3 16-23

Kenneth, R. (1994). The why, who and how of the editorial page. Pennsylvania:

Strata Publishing Company.

Kukah, M. H (1999) Democracy and Civil Society in Nigeria. Spectrum Books Ltd., Ibadan, Nigeria.

Le, E. (2003). Information sources as a persuasive strategy in editorials - Le Monde and The New York Times. Written Communication, 20 (4): 478-510.

Elyazale, N. (2014). Characteristics of Newspaper Editorials: 'Chouftchouf' in 'Almassae' Moroccan Newspaper as a Case Study. New Media and Mass Communication. Vol.32, 2014

Malemi, E. (1999). Mass Media Law. Princeton Publishing Company, Ikeja, Lagos.

Miftahu, I. (2020). Capital Flight, Corruption and Unemployment Rate in Nigeria: An Analytical Review of Economic Performance. International Journal of Social Sciences and Humanities Reviews Vol.10 No.3 10. 261-273.

McCombs, M. (2004). Setting the agenda: the mass media and public opinion. Malden, MA: Blackwell.

Mohn, E. \& McComb, M. (1980) Survey for the National Conference of Editorial Writers. Minneapolis Sur and Tribune Co. Then at Syracuse University.

Momoh, T. (2003). “Thought on Curricular Design for Media Laws, Ethics and Regulations”. A paper presented at national workshop on Curricular review of mass communication training institutions, at gate way Hotel, Abeokuta. November 18-20-2003

Mott, G. (1940). An Outline survey of journalism.College outline series. New York: Barnes \& Noble. 
Morley, J. \& Murphy, A (2005). The peroration revisited: persuasion in two newspaper discourse types. Paper presented in The $15^{\text {th }}$ European Symposium on Languages for Special Purposes titled New Trends in Discourse, University of Bergamo, Italy, 29thAugust - 2nd September 2005.

Murphy, A. (2005). A Corpus based contrastive study of evaluation in English and Italian. Milano: ISU UniversitàCattolica.

Ogbondah, C.W (1992). British Colonial Authoritarianism, African Military Dictatorship and the Nigerian Press. Africa Media Review, Vol. 6 No. 3

Okolo, P.O. \& Raymond, A.O. ( 2014). Corruption in Nigeria: The Possible Way Out .Global Journal of Human Social Science: Political Science Volume 14 Issue 7 Version 1.0

Omu, F. (1978). Press and Politics in Nigeria 1880-1937 Longman Publisher London.

Park, R, E. (1923), "The Natural History of the Newspaper”, The American Journal of Sociology, Vol 29, No 3, PP. 273-289.

Paul, N, R. (1992), Publication Design.5, (ed.) New York: ACM Press

Pratt C. B (1990). Ethics in newspaper editorials: Perceptions of sub-Sahara African journalists

Richardson, J. E. (2007). Analysing newspapers: An approach from critical discourse analysis. Basingstoke [England]; New York, NY: Palgrave Macmillan.

Roach, T.J. (2006) "Expository rhetoric and Journalism" Encyclopaedia of Rhetoric. Oxford University Press.

Schudson, M.(2001). Newspaper Editorials and Comment Articles: A "Cinderella" Genre? The Objectivity Norm in American Journalism, Journalism, 2 (2),149-170,2001.

Sinclair, J.M., \& M.R. Coulthard. (1975). Towards an Analysis of Discourse: The English used by teachers and pupils. Oxford: Oxford University Press.

Sowunmi, A. R. (2010). The Role of Media in Curbing Corruption in Nigeria. Research Journal of Information Technology, 7-23.

Stokhof, M. (2018). Ethics and morality, principles and practice. Zeitschrift für Ethik und Moral philosophie. Vol. 1, pp. 291-304

Stople, O. (2008). Corruption and Anticorruption in Nigeria and beyond. A Paper presented at one day workshop on Reporting corruption in Nigeria Organised by the United Nations Office on Drug and Crime (UNODC), in collaboration with the Economic and Financial Crimes Commission (EFCC) and the Nigeria Union of Journalists (NUJ).

Tobechukwu, E. N. \& Olaitan J. (2009) Analysis of the Content of Nigeria's Newspaper Editorials Oko Journal of Commuqication\& Information Science vol.1, no. 2

Transparency International, (2020). Corruption Perception Index. Available: https://www.transparency.org/en/cpi/2020

UN (2020). Tackling illicit financial flows for sustainable development in Africa. Available: https://www.un.org/africarenewal/magazine/july-2021/tackling-illicit-financial-flows-matter-survivalafricas

Van Dijk, T. A. (1988). News as Discourse. Hillsdale, NJ: Erlbaum Print.

Van Dijk, Teun, A. (1995). Discourse, Opinions and Ideologies. Current Issues in Language and Society, Vol 2, No2, PP. 1-23.

Van Dijk, T. A (1995). Discourse Analysis as Ideology Analysis. Language and Peace. Ed. Wenden, Claudia Schäffner \& Aren. Aldershot: Dartmouth Publishing. 17-33. Print.

Van Dijk, T. A. (1996), Opinion and Ideologies in Editorials. Paper for the Fourth Annual International Symposium of Critical Discourse Analysis, December 14-16, Athens, http://www.discourse.org/unpublishedarticles/opinion\%20ideologies\%20in\%20editorials.htm.

Virtanen, T. (2005). Polls and surveys show: Public opinion as a persuasive device in editorial discourse. In $\mathrm{H}$. Halmari and T. Virtanen, eds., Persuasion Across Genres. A linguistic approach. 153-180. Amsterdam/Philadelphia: John Benjamins.

Westin, I. (1997). The language of English up-market editorials from a 20th century perspective. (FoU-rapport no 39).Gävle: Högskolan i Gävle.

Westin, I. (2001). The language of English newspaper editorials from a 20th-century perspective. PhD dissertation. Uppsala University.

Whitchurch, C. M. (1998). From editorial rhetoric to reality. Perspectives vol. 2 iss. 2

Yusha'u M. J. (2018). Regional Parallelism and Corruption Scandals in Nigeria. Palgrave Macmillan, Cham. https://doi.org/10.1007/978-3-319-96220-7. 